Bond University

Research Repository

\author{
Marine park planning and recreational fishing \\ Is the science lost at sea? Case studies from Australia \\ McPhee, Daryl Peter \\ Published in: \\ The International Journal of Science in Society
}

Link to output in Bond University research repository.

Recommended citation(APA):

McPhee, D. P. (2011). Marine park planning and recreational fishing: Is the science lost at sea? Case studies from Australia. The International Journal of Science in Society, 2(2), 23-37.

\footnotetext{
General rights

Copyright and moral rights for the publications made accessible in the public portal are retained by the authors and/or other copyright owners and it is a condition of accessing publications that users recognise and abide by the legal requirements associated with these rights.
}

For more information, or if you believe that this document breaches copyright, please contact the Bond University research repository coordinator. 


\section{Bond University}

\section{ePublications@bond}

$1-1-2011$

\section{Marine park planning and recreational fishing: Is the science lost at sea? Case studies from Australia}

Daryl McPhee

Bond University, daryl_mcphee@bond.edu.au

Follow this and additional works at: http://epublications.bond.edu.au/sustainable_development Part of the Natural Resources Management and Policy Commons

\section{Recommended Citation}

Daryl McPhee. (2011) "Marine park planning and recreational fishing: Is the science lost at sea? Case studies from Australia" The International Journal of Science in Society, 2 (2), 23-37: ISSN $1836-6236$.

http://epublications.bond.edu.au/sustainable_development/103

This Journal Article is brought to you by the Institute of Sustainable Development and Architecture at ePublications@bond. It has been accepted for inclusion in Mirvac School of Sustainable Development by an authorized administrator of ePublications@bond. For more information, please contact 


\section{THE INTERNATIONAL}

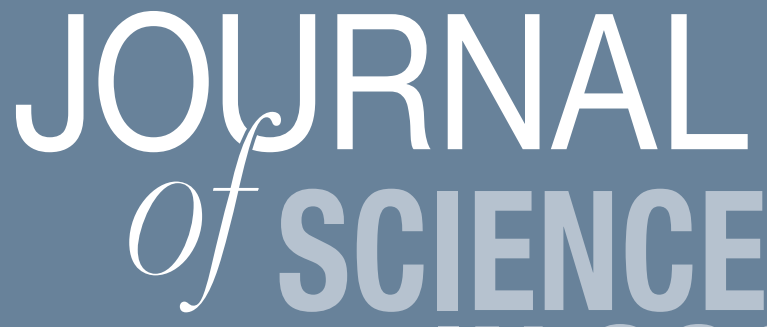

TN SOCIETY

Volume 2, Number 2

Marine Park Planning and Recreational Fishing: Is the Science Lost at Sea? Case Studies from Australia

Daryl McPhee 
THE INTERNATIONAL JOURNAL OF SCIENCE IN SOCIETY

http://science-society.com/journal/

First published in 2011 in Champaign, Illinois, USA

by Common Ground Publishing LLC

www.CommonGroundPublishing.com

ISSN: $1836-6236$

(C) 2011 (individual papers), the author(s)

(c) 2011 (selection and editorial matter) Common Ground

All rights reserved. Apart from fair dealing for the purposes of study, research, criticism or review as permitted under the applicable copyright legislation, no part of this work may be reproduced by any process without written permission from the publisher. For permissions and other inquiries, please contact

<cg-support@commongroundpublishing.com>.

THE INTERNATIONAL JOURNAL OF SCIENCE IN SOCIETY is peer-reviewed, supported by rigorous processes of criterion-referenced article ranking and qualitative commentary, ensuring that only intellectual work of the greatest substance and highest significance is published.

Typeset in Common Ground Markup Language using CGPublisher multichannel typesetting system

http://www.commongroundpublishing.com/software/ 


\title{
Marine Park Planning and Recreational Fishing: Is the Science Lost at Sea? Case Studies from Australia
}

\author{
Daryl McPhee, Bond University, Queensland, Australia
}

\begin{abstract}
No take" marine parks are widely advocated and increasingly utilised as a tool aimed at protecting marine biodiversity, and they may also be used as a fisheries management tool. In Australia a national system of no-take marine parks is being established to protect marine biodiversity. The creation of this network of no-take marine parks that exclude the public from recreational fishing in large areas of the ocean is extremely contentious. Nearly one quarter of the Australian population goes recreational fishing at least once a year, and it is a \$2 billion industry. The motivations for, and aspirations of these recreational anglers are extremely diverse. While there is a clearly documented and accepted need to engage stakeholders through consultation and participation, there has been little focus in considering how the marine science associated with marine parks is communicated to, and interpreted by, recreational fishers. It is generally presented as value neutral information when in fact it can be demonstrated to frequently be value laden and the underlying values are increasingly inconsistent with many recreational fishers' observations of the natural environment which they interact with. The application of marine science in the context of marine parks has significant social and economic impact, and it is contested that these impacts are rarely understood clearly by most scientists active within the discipline, however views on them are offered that are frequently unchallenged by decision makers. In this paper, a number of Australian marine park case studies from urban and rural areas are used to examine identified contentions in detail. Potential solutions to challenges and contentions that have been encountered are presented.
\end{abstract}

Keywords: Marine Parks, Australia, Recreational Fishing, Biodiversity Conservation, Fortress Conservation

\section{Introduction}

A

N EMERGED PARADIGM for the management of marine ecosystems is spatial management through marine reserves, but it is highly contentious. The benefits for biodiversity conservation and fisheries management of "protection" through implementing marine reserves are often claimed to be universal and unquestionable and these claims are often made through "scientific consensus statements"1. While benefits of marine reserves (however measured) for biodiversity conservation and fisheries management are plausible and have been documented empirically, they are not universal. Rather, the benefits of marine reserves are strongly influenced by: the biology and ecology of individual species and their interaction with habitat, the fisheries management regime in place including enforcement, and the overall anthropogenic impacts (including non-fishing impacts) on the marine environment (e.g. Boesch et al., 2001; Jones et al., 2004).

\footnotetext{
${ }^{1}$ Examples of such statements include http://www.jiwlp.com/contents/Marine_Reserves_Report.htm and http://www.ecology.uq.edu.au/docs/Marine\%20Reserve\%20Scientist\%20Ltr\%2018Aug2010.pdf
}

The International Journal of Science in Society 
There is a growing body of literature which documents institutional and societal issues associated with marine reserves (e.g. Klein et al., 2008; Charles and Wilson, 2009; Marshall et al., 2009; De Santo et al., 2010; Ferse et al., 2010; Mascia et al., 2010). The issues identified include the need for meaningful participation in design, management and monitoring; dislocation and displacement of fishers; costs and benefits of marine reserves and their distribution; governance arrangements; and the nature of existing access rights. While the literature to date has focussed on marine reserves and issues associated with commercial fishing, and subsistence fishing in developing countries, the main focus of this paper is marine reserves and the recreational fishery.

Since 1991 Australian governments have been committed to the development and implementation of a National Representative System of Marine Protected Areas (NRSMPA). The aim of this system is biodiversity protection and the NRSMPA contains commitments to implement "highly protected areas" in each marine bioregion of Australia ${ }^{2}$. These highly protected areas include marine reserves ${ }^{3}$ where all fishing activities are prohibited and this has generated conflict and resulted in organised direct action by recreational fishing interests (e.g. public rallies ${ }^{4}$ ) as well as government inquiries. Marine reserves have been the subject of numerous statements in various state parliaments and the Federal parliament; and were one of the dominant conservation and natural resource management issue at the most recent (2010) Federal election. Conflict between government agencies, non-government organisations and fishing interests is also documented in countries other than Australia (e.g. Pearce, 2002; Weible, 2008; De Santo et al., 2010).

In Australia, recreational fishing is the nation's biggest participation sport with an estimated 3.4 million people fishing at least once a year, which represents $19.5 \%$ of the Australian population at the time of surveying (Henry and Lyle, 2003). The reasons people go fishing are diverse and include catch related (e.g. the thrill of catching a big fish) and non-catch related motivations such as "being with friends" and "being outdoors". Recreational fishing participation in Australia is high on a global scale but behind a number of European countries including Lithuania, Sweden and Finland (Ditton, 2008). Recreational fishing in Australia is generally focussed in estuaries and inshore coastal waters and the recreational catch is diverse in terms of species targeted and species retained (Henry and Lyle, 2003). Nationally, expenditure on recreational fishing goods and services was estimated to be $\$ 1.85$ billion annually in 2001/2002 (Henry and Lyle, 2003). Recreational fisheries are typically managed by a number of management tools including: general or specific recreational fishing licences, restrictions on fishing gear, bag limits which limit the catch of individual anglers or groups of anglers; and size limits that typically prevent the harvesting of small fish (minimum legal sizes), but may also be designed to prevent the harvest of large fish (maximum legal sizes).

The main points of contention from recreational fishing interests in Australia regarding marine reserve declaration include:

- The costs of marine reserves for recreational fishers are poorly understood by marine park planners, poorly assessed or not assessed at all;

\footnotetext{
${ }^{2}$ A bioregion is an area which is similar in terms of physical attributes as well as flora and fauna assemblages.

${ }^{3}$ While there a number of different terms in use, herein this paper will use the term marine reserve to refer specifically to areas where no fishing is permissible (no-take areas) and the term marine park to refer to the multiple use areas.

${ }^{4}$ An example can be seen at http://www.youtube.com/watch?v=yhXftjTxNQM
} 
- The benefits from marine reserves for recreational fishers are overstated and not necessarily of local relevance;

- Marine reserves do not mitigate against a large number of non-fishing hazards and risks particularly relevant to the coastal region; and

- A perceived lack of opportunity for meaningful input into the exact location and size of marine reserves.

These main points were identified from discussions with recreational fishers, a review of publicly available submissions to proposed marine reserves and from a review of various recreational fishing web forums 5 . This paper discusses and analyses these main points of contention from the perspective of the available scientific information (biological/ecological and social) and its translation into a public policy response - the implementation of marine reserves. Changes to the approach of developing marine reserve networks to reduce conflict are proposed.

\section{Costs and Benefits of Marine Reserves for Recreational Fishers}

Smith and Wilen (2003) make the point that historically marine reserves have been promoted by biologists/ecologists with little input solicited from economists or social scientists. Literature in support of marine reserves often has a significant focus on describing the benefits of marine reserves. In fact, a number of review documents in support of developing marine reserves in Australia, specifically refer to environmental benefits of marine reserves only (for instance see: Baker, 2000; Kenchington et al., 2003; Marine Parks Authority, 2008).

Recreational anglers frequently consider marine reserves to result in costs - namely loss of fishing access to a specific location or locations. Additional costs on individual fishers may be incurred as a result of displaced fishers moving to fish in areas remaining open, thus potentially increasing crowding which is frequently an important factor in satisfaction levels within an outdoor leisure setting. (e.g. Shelby et al., 1989; Manning et al., 2000; Stewart and Cole, 2001). There is yet to be any detailed studies that focus on quantifying the redistribution of recreational fishing effort as a result of marine reserves and the impacts of any redistribution that does occur on satisfaction levels. Thus from a societal perspective, the question is not solely about the benefits, it is about the costs and the benefits. The costs for affected recreational fishers of marine reserve declaration (e.g. loss of access) are tangible and immediate, while the benefits are less tangible and may be longer term, if they occur at all (Scholz et al., 2004; Cook and Heinen, 2005).

A review of stated costs and benefits for the recreational fishing sector for a number of Australian marine parks that include marine reserves is presented in Table 1. It is noteworthy that no detailed recreational fishing cost-benefit analyses for marine reserves were found in any of the case studies reviewed, or indeed in the peer reviewed literature. Where costs were identified they were done so in very general terms and not identified as being significant or persistent. Where fisheries benefits were identified they pertained to increased "spillover", enhanced fish stocks and fish habitats including for recreational species and in the case of the Great Barrier Reef Marine Park, enhance the region's reputation as a fishing destination. From the case studies examined and included in Table 1, two points will be discussed further. The first is the concept of "spillover" of adults and eggs or larvae as it pertains to purported

\footnotetext{
${ }^{5}$ Examples include www.ausfish.com.au and www.strikehook.com
} 
fisheries. The second is the notion that impact (cost) is small, if only a small number of recreational fishers are potentially impacted.

Table 1: Marine Reserve Cost and Benefit Analysis for Recreational Fishing Benefits

\begin{tabular}{|c|c|c|}
\hline Location & $\begin{array}{c}\text { Stated Potential Costs or Negative } \\
\text { Impacts }\end{array}$ & $\begin{array}{c}\text { Stated Potential Benefits or } \\
\text { Positive Impacts }\end{array}$ \\
\hline $\begin{array}{l}\text { Moreton Bay } \\
\text { Marine Park }\end{array}$ & $\begin{array}{l}\text { The draft zoning plan will have a direct } \\
\text { impact on approximately five percent } \\
\text { of recreational fishing trips conducted } \\
\text { inside the marine park. } \\
\text { Various types of recreational fishing } \\
\text { occur throughout Moreton Bay Marine } \\
\text { Park, however effort is clearly concen- } \\
\text { trated in areas with easy accessibility. } \\
\text { A wide range of easily accessible altern- } \\
\text { ative fishing locations are still available } \\
\text { under the draft zoning plan, therefore it } \\
\text { is anticipated that the direct impact will } \\
\text { be replaced by effort shifting to substi- } \\
\text { tute fishing locations near proposed } \\
\text { green zones. }\end{array}$ & $\begin{array}{l}\text { The benefit of marine parks, particu- } \\
\text { larly from green zones (marine re- } \\
\text { serves), on fish stocks has been } \\
\text { widely studied and reported in nu- } \\
\text { merous scientific articles and texts. } \\
\text { There is increasing evidence that } \\
\text { green zones replenish fish popula- } \\
\text { tions regionally. This has been ob- } \\
\text { served in increasing fish density, } \\
\text { size, biomass or abundance, and } \\
\text { 'spillover' of species into adjacent } \\
\text { fished areas. }\end{array}$ \\
\hline $\begin{array}{l}\text { Batemans } \\
\text { Marine Park }\end{array}$ & $\begin{array}{l}\text { There is no consensus on the likely im- } \\
\text { pact of zoning in the proposed Marine } \\
\text { Park on recreational fishing. }\end{array}$ & $\begin{array}{l}\text { There is no consensus on the likely } \\
\text { impact of zoning in the proposed } \\
\text { Marine Park on } \\
\text { recreational fishing. }\end{array}$ \\
\hline $\begin{array}{l}\text { Great Barrier } \\
\text { Reef Marine } \\
\text { Park }\end{array}$ & $\begin{array}{l}\text { All indications are that the revised zon- } \\
\text { ing Plan will have minimum impact on } \\
\text { recreational fishers even if anecdotal } \\
\text { information suggests that these data are } \\
\text { slight underestimates. The frequency } \\
\text { and/or cost of fishing trips are unlikely } \\
\text { to be affected by the increased area of } \\
\text { marine reserves throughout the Marine } \\
\text { Park. }\end{array}$ & $\begin{array}{l}\text { It is likely that, in the medium to } \\
\text { long term, more marine reserves as } \\
\text { proposed in the revised Zoning Plan } \\
\text { will enhance the Great Barrier } \\
\text { Reef's reputation as a fishing destin- } \\
\text { ation. }\end{array}$ \\
\hline
\end{tabular}




\begin{tabular}{|c|c|c|}
\hline $\begin{array}{l}\text { Port Stephens } \\
\text { - Great Lakes } \\
\text { Marine Park }\end{array}$ & $\begin{array}{l}\text { Marine reserves may be a source of } \\
\text { some initial dislocation to recreational } \\
\text { fishing patterns. }\end{array}$ & $\begin{array}{l}\text { Research has identified a number of } \\
\text { benefits for ecosystems, habitats and } \\
\text { species from the creation of marine } \\
\text { protected areas, including: improved } \\
\text { fish stocks as a result of the protec- } \\
\text { tion of habitats critical for commer- } \\
\text { cially and recreationally important } \\
\text { species; and dispersal of larval re- } \\
\text { cruits and genetic diversity to sur- } \\
\text { rounding areas. } \\
\text { Although marine parks may be a } \\
\text { source of some initial dislocation to } \\
\text { recreational fishing patterns, through } \\
\text { the impact of sanctuary zones, it is } \\
\text { anticipated that these effects would } \\
\text { be offset by enhanced recreational } \\
\text { fishing experiences (both quantity } \\
\text { and quality of catch) }\end{array}$ \\
\hline $\begin{array}{l}\text { South Aus- } \\
\text { tralian Mar- } \\
\text { ine Parks }\end{array}$ & None identified & $\begin{array}{l}\text { Sanctuary zones result in many bene- } \\
\text { fits, including: refuges for vulner- } \\
\text { able species; habitat protection and } \\
\text { habitat recovery; development of } \\
\text { natural biological communities; spill } \\
\text { over of adults and juveniles into } \\
\text { fishing grounds; and enhanced pro- } \\
\text { tection of offspring which can re- } \\
\text { stock fishing grounds. }\end{array}$ \\
\hline \multicolumn{3}{|c|}{$\begin{array}{l}\text { * Marine Parks (Moreton Bay) Zoning Plan } 2008 \text { Regulatory Impact Statement for SL } 2008 \\
\text { No. } 343 \\
\text { ** Socio-Economic Assessment of the Batemans Marine Park, } \\
\text { http://www.mpa.nsw.gov.au/pdf/bmp-socio-economic-report.pdf (accessed 28/9/10) } \\
\text { *** Zoning Plan for the Great Barrier Reef Regulatory Impact Statement. } \\
\text { **** Socio-Economic Assessment of the Port Stephens - Great Lakes Marine Park } \\
\text { **** Blueprint for the South Australian Representative System of Marine Protected } \\
\text { Areas(http://www.environment.sa.gov.au/coasts/pdfs/mpa_blueprint.pdf) }\end{array}$} \\
\hline
\end{tabular}

\section{The Spillover Effect}

The biodiversity benefits from marine reserves can include increased biomass, species richness and average size in marine park areas compared to similar areas where fishing remains permissible. There are a large number of studies from a variety of locations and habitats that demonstrate this (e.g. Ferreira and Russ, 1995; Edgar and Barrett, 1999; McClanahan and Arthur, 2001; Willis et al., 2003; Williamson et al., 2004), but the implied biodiversity benefits of marine reserves are by no means universal (see Jones et al. 2004). Frequently however, 
it is implied that biodiversity benefits are universal, and fisheries benefits also accrue. In fact, marine reserves established for marine biodiversity conservation are often "sold" to stakeholders explicitly or implicitly on the basis of fisheries benefits. However, for a benefit to a fishery to accrue from a marine reserve, a simple build up of biomass or an increase in species richness or the average size of fish is not sufficient in itself. There needs to be a "spillover" of either adult fish or eggs and larvae from the marine reserve to areas where fishing access remains.

The spillover of adult fish is influenced by the movement dynamics of a species relative to marine reserve size and how exploited species respond to density dependent effects within the marine reserve (e.g. Le Quesne and Codling, 2009; Moffitt et al., 2009; Miethe et al., 2010; Kellner et al. 2010). Additional biological/ecological factors that influence adult spillover can include body size, habitat, depth range, and schooling behaviour (Claudet et al., 2010). Where adult spillover has been demonstrated through modelling or empirical studies, it has been generally found to be limited spatially to 100 s metres from the marine reserve boundary (Russ, 2004; Halpern et al., 2010). If the adult spillover effect is too large it may compromise the achievement of biodiversity outcomes in some instances by limiting the retention of exploited species within the marine reserve itself (Mora et al., 2006; Miethe et al., 2010).

For the spillover of eggs and larvae from a marine reserve to a fished area to be relevant, it requires in the first instance for the fished species to reproduce within the marine reserve, and egg production to be enhanced as a result or more and/or larger fish within the marine reserve If fished species do not reproduce in a marine reserve, then benefits derived from egg and larval spillover are not plausible. The magnitude of egg and larval spillover is extremely difficult to assess empirically and most analyses have relied upon modelling (e.g. Halpern et al., 2004). Even if marine reserves do result in more eggs and larvae are produced, it does not follow that fish recruitment levels will always increase with higher levels of egg production. This is because the spawning stock-recruitment relationship is asymptotic with the asymptote reached between $10 \%$ and $60 \%$ of unfished levels depending on the species (Penn and Fletcher, 2010). Further, there is scant evidence that marine species are limited by the number of propagules (eggs and larvae). What is more important is how many of these propagules recruit to suitable nursery habitat which promotes their survival. Again, it is critical to consider the individual biology of the species, this time in concert with hydrodynamic factors and environmental quality within and adjacent to marine reserves, and the fisheries management regime.

From this discussion, it is clear that spillover effects can occur and are documented within the scientific literature. It is also clear that they are not universal and depend on a range of species specific biological and ecological factors. From this it is concluded that broad statements of benefits to recreational fisheries used in Australia to support marine reserve implementation through spillover effects is an oversimplification.

\section{Understanding the Impact of Marine Reserves on Recreational Fishers}

Understanding the heterogeneity of recreational fishers and their behaviour is an important consideration for marine reserve planning. The reasons that people go recreational fishing are diverse and include both catch and non-catch related motivations. Within the recreational fishery a number of 'sub-sectors' can be identified and these sub-groups can differ with respect 
to the specific recreational fishing methods used by the fishers, the relative importance of catch and non-catch related motivations, investment in fishing equipment, the frequency of fishing (avidity) and the spatial distribution of fishing activity (Lynch, 2006; Arlinghaus, et al., 2008; McPhee, 2008).

The generally accepted concept for understanding the diversity of recreational fishing participants is 'recreational specialisation' (e.g. Fisher, 1997; Oh and Ditton, 2006; 2008). The concept identifies that along a continuum of specialisation, various sub-sectors of recreational fishers can be identified based on factors such as frequency of participation, capital investment in fishing equipment, the importance of catching fish, the social setting of the fishing activity. At one end of the continuum are 'once a year fishers' who have little investment in capital equipment, may not place a high importance on catching fish, and have limited understanding of resource management. For these fishers, fishing is not necessarily an important leisure activity and may be easily substituted for by other outdoor leisure activities with no little or no impact on satisfaction levels. Importantly in the context of marine reserves, the experience may be very easily substituted spatially. That is, simply going fishing elsewhere. At the other end of the continuum are recreational fishers who fish frequently, have a high investment in fishing equipment, place a high value on catching fish. For these fishers, fishing is their principal leisure activity and may not be substituted for by other outdoor leisure activities to achieve a similar level of satisfaction. While the latter group tend to numerically represent a minority of recreational fishers, they are the fishers that have the greatest investment in the activity in social and economic terms. Importantly in the context of marine reserves, the experience may not be very easily substituted spatially. The locations where the specialised form of recreational fishing that maximises an individual's satisfaction level may be very limited or in fact unique.

Conceptualising the recreational fishery as a continuum of specialisation explains in part the apparent disconnect between the small number of recreational fishers that government agencies claim are impacted by marine reserves, and the significant conflict that has occurred. Highly specialised anglers, with large psychological, social, and financial investments in fishing, are likely to voice the strongest opinions (either in favour or opposition), in response to management actions including marine reserves (Salz and Loomis, 2005). Additionally, those that may be disproportionately impacted are those anglers that may have limited ability to respond to change and spatially adapt their fishing activities. This includes the younger and older components of the population as well as those with physical disabilities, or those that are suffering financial hardship. These groups of people may have limited access to transport and/or limited physical mobility which potentially limits their ability to change the spatial pattern of their fishing activities. It is clearly plausible that only a limited number of recreational fishers are impacted by marine reserves and Sutton and Tobin (2009) identified that this was the case for the Great Barrier Reef Marine Park. However, recreational fishers impacted are likely to be disproportionally those that have the most to lose and least able to adapt spatially to change to achieve the same or similar satisfaction levels from their preferred leisure activity.

Incorporation of specialisation theory into studies of recreational fishing and marine reserves can improve the understanding of important cognitive differences that exist among diverse recreational participants and that potentially drive conflict. In addition to this, the ability of anglers to adapt spatially to change needs to be considered. Failure to consider these issues to date in Australia is a reflection of the lack of attention paid to understanding 
social issues in general in marine reserve planning (Mascia et al., 2010). While biological and ecological studies are important in marine reserve design and implementation, it is argued that studies based on social science are equally important given that marine reserves are about altering human behaviour, in particular that of fishers (Jones, 2006; Charles and Wilson, 2009).

\section{Mitigation of Environmental Hazards and Risks}

The consideration of environmental hazards and the mitigation of environmental risks is at the forefront of environmental management in general. Marine reserves ostensibly mitigate only one hazard and risk to the marine environment - namely fishing, and in the coastal zone this is not necessarily the most significant hazard or risk (Boesch et al., 2001), especially in regions where effective fisheries management occurs. Hazards and risks other than fishing include water quality impacts that arise from urban and rural runoff and point source discharges (e.g. sewage outlets) which can include nutrients and various toxicants, accidents such as oil spills, the introduction of invasive species and their spread, changes to the timing and volume of freshwater inputs, and habitat destruction or modification from various forms of coastal development (e.g. Bailey et al., 2000; Boesch et al., 2001; Halpern et al., 2007; Ogburn et al., 2007; Lewis, 2009).

The risk posed by a number of toxicants (e.g. endocrine disrupters) and nanoparticles in the marine environment is only becoming understood in a rudimentary way and while uncertainties exist, there is significant cause for concern (Ross et al., 2009; Canisi et al., 2010; Wong et al., 2010). There is a lack of understanding of the cumulative exposure of marine organisms to various toxicants, particularly during early life history (larval) stages that are known to by highly sensitive to chemicals. These hazards and risks are particularly important in coastal areas where large population centres or significant agricultural or industrial development occur and this includes many existing and proposed marine reserve locations in Australia. Because water quality impacts cross marine reserve boundaries and potentially compromise larval spillover and other recruitment processes, marine reserves are largely ineffective at mitigating them (Dee Boersma and Parrish, 1999).

Overall, marine reserves do not provide any protection from introduced marine species and water quality impacts and only limited or no protection (depending on the jurisdiction) against developments that impact habitat. In fact, recent work has suggested that marine reserves may make a marine community as a whole more susceptible to invasion by introduced species as a result of increasing the spatial heterogeneity of habitats at a regional level (Kellner and Hastings, 2009; Halpern et al., 2010). Such work highlights again the need for a more considered and focussed assessment of the costs and benefits of marine reserves rather than an oversimplified assumption that they are of clear benefit.

There is a clear disconnect between the hazards and risks to marine biodiversity and the principal tool currently advocated and utilised to attempt to protect it (marine reserves). This disconnect is not communicated to the general public in marine reserve planning documents, but is well known by recreational fishers and a key contention. The inability of marine reserves to provide direct protection against non-fishing impacts is a clear limitation of the tool for the conservation of marine biodiversity. It is not a reason to cease marine reserve declaration, but it is reason for a rethink of what tools are best for mitigating hazard and risk in the marine environment. There is a high likelihood that widespread implementation of marine reserves 
will lull the general population into a false sense of security that the marine environment is somehow "protected", while root causes of marine biodiversity and fisheries decline continue unchecked.

Marine reserves should be incorporated in a risk based approach to management of marine systems where they mitigate key identified risks from fishing at a regional or local level. Where risks cannot be plausibly mitigated through the development and implementation of marine reserves, other tools should be utilised. The available information clearly suggests that ability of marine reserves to mitigate non-fishing risks is limited (or absent), and as such they should not be promoted as doing so either explicitly or implicitly.

\section{Participatory Approaches for Marine Reserve Design and Monitoring}

The overall approach commonly used to develop and implement marine parks (including marine reserves) in Australia is best described as a technocratic approach with extensive public consultation. Baelde (2005) identifies that participatory practices for marine reserve planning in Australia are very limited or non-existent with a heavy reliance on simple consultative mechanisms such as public meetings and/or circulation of information. Recreational fishers have been identified as being dissatisfied with the consultation process in the Great Barrier Reef Marine Park rezoning due to perceptions that: 1) the outcomes of the process were predetermined; 2) recreational fishers were not treated fairly compared to other stakeholders; and 3) there was insufficient feedback about how information provided by recreational fishers was used in the process (Sutton and Tobin, 2009). No such detailed assessments exist for other marine parks in Australia. The benefits of effective participation by stakeholders (including recreational fishers) in marine reserves include increased support and compliance and it also allows for marine reserve planners to take advantage of expert local knowledge of the marine environment (Baelde, 2001; Manson and Die, 2001; Lunn and Deardon, 2006; Charles and Wilson, 2009). A participatory approach can also lead to the collection of information on fishing activities at a fine scale which can potentially aid the mitigation of conflict (Scholz, et al., 2004).

While the design of marine reserves networks in Australia haslacked effective participatory approaches, there has been some effort at building research partnerships with the local communities including recreational fishers. The best example of this is in the Capricorn region of the Great Barrier Reef Marine Park where Almany et al. (2010) identified that successful engagement was achieved by: 1) early engagement by collaborating organisations to build trust; 2) ensuring scientific questions have direct relevance to the community; 3) providing appropriate incentives for participation; and 4) clear and open communication.

To foster a more socially inclusive and less confrontational approach to marine reserve design and management, participatory approaches to the design of marine reserves should be embraced by government. The approach described for successful participation with the community including recreational fishers in the Capricorn region of the Great Barrier Reef Marine Park has broad applicability and could be widely utilised. For such approaches to be effective however, recreational fishing interests need to have effective social capital and be able to provide effective leadership. While it is not considered realistic that more participatory approaches will lead to complete consensus from the recreational fishing sector on marine reserve design, it is however considered to be highly likely that conflict can be reduced by pursuing such approaches. 


\section{Discussion}

This paper has investigated the major identified contentions raised by recreational fishing interests in regard to the development and implementation of marine reserves for biodiversity protection in Australia. With reference to the scientific literature base (biological and social), the major contentions have been demonstrated to have validity. This conclusion does not mean that marine reserves should be dismissed as either a biodiversity conservation tool or a fisheries management tool. Rather it suggests that changes to the way: a) marine reserve networks are developed, and b) costs and benefits to the recreational fishery are conceptualised and communicated, are warranted. Failing to do this will most likely lead to continued conflict. More critical evaluation of the science behind marine reserves, particularly related to spillover effects is warranted, as is a more generally consideration of the individual biology of key species and the dynamics of marine ecological assemblages.

At a conceptual level, it needs to be acknowledged by decision making agencies that marine reserves have both potential costs and benefits for the recreational fishery, and not just benefits. This acknowledgement then needs to be translated into rigorous cost-benefit analysis that includes analysis of social issues of relevance to the recreational fishery. Such an analysis needs to take into consideration that costs and benefits will not be spread evenly through a recreational fishing population as the population itself is heterogeneous, and the ability of recreational fishers to adapt to change to achieve a similar level of satisfaction from the activity is highly variable. Undertaking a cost-benefit analysis approach is consistent with developing a network of marine reserves that minimises social and economic cost which is an identified imperative ${ }^{6}$ but to date an imperative that has not been enacted in any meaningful way for recreational fisheries affected by marine reserves in Australia.

The biodiversity conservation benefits within a marine reserve are documented in a large number of habitats globally, but the benefits are not universal and will most likely fail to occur in degrading environments or where fisheries are well managed (Jones et al. 2004; Myers and Ambrose 2009). Benefits can accrue outside of marine reserves and this potentially includes benefits to recreational fisheries through spillover. This however is contentious as magnitude and spatial scale of spillover is species and area specific and is likely to be highly dependent on environmental quality. Such an important complexity that is meaningful to recreational fishers is not effectively acknowledged in government documents and reports that underpin marine reserve network development in Australia. Instead, all encompassing benefits have frequently been postulated which is inconsistent with available scientific information and inconsistent with the views of recreational fishing interests in general. The "sale" of marine reserves for marine biodiversity conservation on the basis of fisheries benefits is potentially counter-productive as it detracts from the legitimacy of marine biodiversity conservation objectives per se and introduces an additional level of complexity into debates (Jones, 2006).To move forward, government agencies in Australia should be more circumspect in claiming broad and direct fisheries benefits from marine reserves for biodiversity conservation, unless detailed aspects of the biology and ecology of key target species are understood, and demonstrable benefits follow from this understanding.

Marine reserves are not effective at mitigating important hazards and risks in coastal systems such as pollution that can cross reserve boundaries. Pollution can directly impact

\footnotetext{
${ }^{6} \mathrm{http} / /$ www.environment.gov.au/coasts/mbp/publications/general/pubs/goals-nrsmpa.pdf
} 
the most sensitive life history stages of marine organisms (larvae) and habitat. Marine reserves only benefit habitat if previously occurring fishing activities (e.g. trawling) that impact habitat are excluded, or other impacts on habitat (e.g. dredging and coastal development) are also excluded. The promotion implicitly or explicitly of marine reserves as a panacea, including for habitat protection and water quality, can potentially create false comfort that important components of the marine environment are protected when in fact the hazards and risks remain unmitigated. Where benefits to habitats and water quality are claimed to be valid they should be supported with identification of the exact mechanisms whereby the proposed marine reserves can achieve them, and the likely magnitude of the benefits to both the environment and stakeholders. Overall, mitigating hazard and risks to marine environments requires a broader approach than current marine reserve initiatives. Approaches that should be adopted are those that identify and rank all relevant hazards and risks, and where appropriate implement management responses to reduce or eliminate hazards and risks.

To assist planning that minimises impacts on the recreational fishery and can potentially lead to broader long-term support for marine reserves, there is a need to move to more participatory approaches. Overall, there is a significant body of literature which documents that the incorporation of participatory approaches in decision making can lead to better social, economic and environmental outcomes in many different contexts (e.g. Hernandez and Kempton, 2003; Walker, 2007; Wheeler et al., 2008). In the case of fisheries and marine reserves, participatory approaches have the potential to be an effective bridge between traditional fisheries management and marine biodiversity conservation. For such participatory approaches to be effective, recreational fishing interests may need assistance in building social capital and leadership skills.

\section{Conclusion}

Overall, there needs to be a significant rethink of how marine parks in Australia that incorporate marine reserves for biodiversity protection are developed and implemented. There needs to be a commitment to more participatory approaches in the design of marine park networks and a wider application of participatory partnerships between scientists, managers and the community in the monitoring of marine reserves. There needs to be consistent acknowledgement from government agencies that marine reserves have potential costs as well as possible benefits to the recreational fishery (and others), and a commitment to robustly assess these costs and benefits. Marine reserve implementation will also be aided by focusing on the potential biodiversity benefits within the marine reserve, rather than hypothesising significant and universal benefits through spillover that, depending on the species, habitats and size and location of the marine reserve, might not eventuate. There needs to be an understanding that marine reserves are not a panacea - they do not mitigate all important impacts on the marine environment. Management of marine biodiversity should be through mitigation of hazards and risks, while includes but is far from limited to, the implementation of marine reserves. 


\section{References}

Almany, G.R., Hamilton, R.J., Williamson, D.H., Evans, R.D., Jones, G.P., Matawai, M., Potuku, T., Rhodes, K.L., Russ, G.R. and Sawynok, B. (2010) Research partnerships with local communities: two case studies from Papua New Guinea and Australia. Coral Reefs 29: 567-576.

Arlinghaus, R., Bork, M. and Fladung, E. (2008) Understanding the heterogeneity of recreational anglers across an urban-rural gradient in a metropolitan area (Berlin, Germany), with implications for fisheries management. Fisheries Research 92: 53-62.

Baelde, P. (2001) Fishers' description of changes in fishing gear and fishing practices in the Australian south-east trawl fishery. Marine and Freshwater Research 52: 411-418

Baelde, P. (2005) Interactions between the implementation of marine protected areas and rights-based fisheries management in Australia. Fisheries Management and Ecology 12: 9-18.

Bailey, H.C., Krassoi, R., Elphick, J.R., Mulhall, A., Hunt P., Tedmanson, L., and Lovell A. (2000) Whole-effluent toxicity of sewage treatment plants in the Hawkesbury-Nepean watershed, New South Wales, Australia, to Ceriodaphnia dubia and Selenastrum capricornutum. Environmental Toxicology and Chemistry 19:72-81.

Baker, J.L. (2000) Guide to Marine Protected Areas Department for Environment and Heritage, South Australia.

Boesch, D., Burreson, E., Dennison, W., Houde, E., Kemp, M., Kennedy, V., Newell, R., Paynter, K., Orth, R. and Ulanowicz, R. (2001) Factors in the decline of coastal ecosystems. Science 293(5535): 1589-1591.

Canesi, L., Fabbri, R., Gallo, G., Valloto, G., Marcomini, A. and Pojana, G. (2010) Biomarkers in Mytilus galloprovincialis exposed to suspensions of selected nanoparticles (Nano carbon black, C60 fullerene, Nano-TiO ${ }_{2}, \mathrm{Nano}_{-} \mathrm{SiO}_{2}$. Aquatic Toxicology 100(2): 168-177.

Charles, T. and Wilson, L. (2009) Human dimensions of marine protected areas. ICES Journal of Marine Science 66: 6-15.

Claudet, J., Osenberg, C.W., Domenici, P., Badalamenti, F., Milazzo, M., Falcon, J.M., Bertocci, I., Benedetti-Cecchi, L., Garcia-Charton, J.A., Goni, R., Borg, J.A., Forcada, A., de Lucia, G.A., Pérez-Ruzafa, A., Afonso, P., Brito, A., Guala, I., Le diréach, L., Sanchez-Jerez, P., Somerfield, P.J. and Planes, S. (2010) Marine Reserves: Fish life history and ecological traits matter. Ecological Applications 20(3): 830-839.

Cook, G.S. and Heinen, J.T. (2005) On the uncertain costs and tenuous benefits of marine reserves: a case study of Tortugas Ecological Reserve, South Florida, USA. Natural Areas Journal 25(4): 390-396.

Cooke, S.J. and Cowx, I.G. (2004) The role of recreational fishing in global fish crises. Bioscience 54: 857-859.

Cudrey-Bueno, R., Lavin, M.F., Marinone, S.G., Raimondi, P.T. and Shaw, W.W. (2009) Rapid effects of marine reserves via larval dispersal. PLOS ONE 4(1): e4140. Doi:10.1371/journal.pone. 0004140 .

De Santo., E.M., Jones, P.J.S. and Miller, A.M.M. (2010) Fortress conservation at sea: A commentary on the Chagos marine protected area. Marine Policy Doi:10.1016/j.marpol.2010.09.004

Dee Boersma, P. and Parrish, J.K. (1999) Limiting abuse: marine protected areas, a limited solution. Ecological Economics 31: 287-304.

Ditton, R. (2008) An International Perspective on Recreational Fishing. In: O Aas (ed) Global Challenges in Recreational Fisheries. p. 5-12.

Edgar, G.J. and Barrett, N.S. (1999) Effects of the declaration of marine reserves on Tasmanian reef fishes, invertebrates and plants. Journal of Experimental Marine Biology and Ecology 242: 107-144.

Ferreira, B.P. and Russ, G.R. (1995) Population structure of the leopard coral grouper, Plectropomus leopardus, on fished and unfished reefs off Townsville, central Great Barrier Reef, Australia. Fishery Bulletin 93(4): 629-642. 
Ferse, S.C.A., Costa, M., Máňez, K.S., Adhuri, D.S. and Glaser, M. (2010) Allies, not aliens: increasing the role of local communities in marine protected area implementation. Environmental Conservation 37(1): 23-34.

Fisher, M. R. (1997) Segmentation of the angler population by catch preference, participation, and experience: A management-oriented application of recreation specialization. North American Journal of Fisheries Management 17: 1-10.

Halpern, B.S., Gaines, S.D. and Warner, R.R. (2004) Confounding effects of the export of production and the displacement of fishing effort from marine reserves. Ecological Applications 14(4): 1248-1256.

Halpern, B.S., Selkoe, K.A., Micheli, F. and Kappel, C.V. (2007) Evaluating and ranking the vulnerability of global marine ecosystems to anthropogenic threats. Conservation Biology 21(5): 1301-1315.

Halpern, B.S., Lester, S.E. and Kellner, J.B. (2010) Spillover from marine reserves and the replenishment of fished stocks. Environmental Conservation 36(4): 268-276.

Henry, G.W. and Lyle, J.M. (2003) The National Recreational and Indigenous Fishing Survey. Final Report. Fisheries Research and Development Corporation Project No. 99/158. Cronulla, NSW, Australia.

Hernandez, A. and Kempton, W. (2003) Changes in fisheries management in Mexico: Effects of increasing scientific input and public participation. Ocean and Coastal Management 46(6-7): 507-526.

Jones G.P., McCormick M.I., Srinivasan, M. and Eagle, J.V. (2004) Coral decline threatens fish biodiversity in marine reserves. Proceedings of the National Academy of Sciences 101: 82518253.

Jones, P.J.S. (2006) Collective action problems posed by no-take zones. Marine Policy 30: 143-156.

Kellner, J.B. and Hastings, A. (2009) A reserve paradox: introduced heterogeneity may increase regional invisibility. Conservation Letters 2: 115-122.

Kellner, J.B., Nisbet, R.M. and Gaines, S.D. (2008) Spillover from marine reserves related to mechanisms of population regulation. Theoretical Ecology 1: 117-127.

Kenchington, R., Ward, T. and Hegerl, E. (2003) The Benefits of Marine Protected Areas. $5^{\text {th }}$ IUCN World Parks Congress Technical Paper.

Klein, C.J., Chan, A., Kircher, L., Cundiff, A.J., Gardner, N., Hrovat, Y., Scholz, A., Kendall, B.E. and Airam, E. (2007) Striking a balance between biodiversity conservation and socioeconomic viability in the design of marine protected areas. Conservation Biology 22(3): 691-700.

Le Quesne, W.J.F. and Codling, E.A. (2008) Managing mobile species with MPAs: the effects of mobility, larval dispersal, and fishing mortality on closure size. ICES Journal of Marine Science 66: 122-131.

Lewis, S.E. (2009) Herbicides: A new threat to the Great Barrier Reef. Environmental Pollution 157: 2470-2484.

Lunn, K.E. and Dearden, P. (2006) Fishers' needs in marine protected area zoning: A case study from Thailand. Coastal Management 34: 183-198.

Lynch, T.P. (2006) Incorporation of recreational fishing effort into the design of marine protected areas. Conservation Biology 20(5): 1466-1476.

Manning, R., Valliere, W., Minteer, B., Wang, B. and Jacobi, C. (2000) Crowding in parks and outdoor recreation: A theoretical, empirical and managerial analysis. Journal of Park and Recreation Administration 18(4): 57-72.

Manson, F.J. and Die, D.J. (2001) Incorporating commercial fishery information into the design of marine protected areas.Ocean and Coastal Management 44: 517-530.

Marine Parks Authority (2008) A Review of Benefits of M ar ine Protected A reas and Related Zoning Considerations. 
Marshall, N., Marshall, P. and Abdulla, A. (2009) Using social resilience and resource dependency to increase the effectiveness of marine conservation initiatives in Salum, Egypt. Journal of Environmental Planning and Management 52(7): 901-918.

Mascia, M.B., Claus, C.A. and Naidoo, R. (2010) Impacts of marine protected areas on fishing communities. Conservation Biology 24(5): 1424-1429.

McClanahan, T.R. and Arthur, R. (2001) The effect of marine reserves and habitat on populations of East African coral reef fishes. Ecological Applications 11: 559-569.

McPhee, D.P. (2008) Fisheries Management in Australia. Federation Press.

Miethe, T., Dytham, C., Dieckmann, U. and Pitchford, J.W. (2009) Marine reserves and the evolutionary effects of fishing on size at maturation. ICES Journal of Marine Science 67: 412-425.

Moffitt, E.A., Botsford, L.W., Kaplan, D.M. and O'Farrell, M.R. (2009) Marine reserve networks for species that move within a home range. Ecological Applications 19(7): 1835-1847.

Mora, C., Andréfouët,S., Costello, M.J., Kranenburg, C., Rollo, A., Veron, J., Gaston, K.J. and Myers, R.A. (2006) Coral reefs and the global network of marine protected areas. Science 312: 17501751.

Myers, M.R. and Ambrose, R.F. (2009) Differences in benthic cover inside and outside marine protectedareas on the Great Barrier Reef: influence of protection or disturbance history? Aquatic Conservation: M arine and Freshwater Ecosystems 19: 736-747.

Penn, J.W. and Fletcher, W.J. (2010) The Efficacy of Sanctuary Areas for Management of Fish Stocks and Biodiversity in WA Waters. Fisheries Research Report (Western Australia). No. 169.

Ogburn, D.M., White, I. and McPhee, D.P. (2007) What happened to the oyster reefs in east coast Australian estuaries - colonial or mudworm invasion? Coastal Management 35: 271-287.

Oh, C. and Ditton, R. (2006) Using recreational specialization to understand multi-attribute management preferences. Leisure Sciences 28: 369-384.

Oh, C. and Ditton, R. (2008) Using recreation specialization to understand conservation support. Journal of Leisure Research 40(4): 556-573

Pearce, J. (1997) The future of fisheries - marine protected areas - a new way forward or another management glitch. Marine Pollution Bulletin 44: 89-91.

Ross, P.S., Couillard, C.M., Ikonomou, M.G., Johannessen, S.C., Lebeuf, M., Macdonald, R.W., Tomy, G.T. (2009) Large and growing environmental reservoirs of Deca-BDE present an emerging health risk for fish and marine mammals. Marine Pollution Bulletin 58(1): 7-10.

Salz, R.J. and Loomis, D.K. (2005) Recreation specialization and anglers' attitudes towards restricted fishing areas. Human Dimensions of Wildlife 10: 187-199.

Scholz, A., Bonzon, K., Fujita, R., Benjamin, N., Woodling, N., Black, P. and Steinback, C. (2004) Participatory socioeconomic analysis: drawing on fishermen's knowledge for marine protected area planning in California. Marine Policy 28: 335-349.

Shelby, B., Vaske, J. and Heberlein, T. (1989) Comparative analysis of crowding in multiple locations: Results from fifteen years of research. Leisure Sciences 11: 269-291.

Stewart, W. and Cole, D.N. (2001) Number of encounters and experience quality in Grand Canyon backcountry: Consistently negative and weak relationships. Journal of Leisure Research 33(1): 106-1605-1614.

Sutton, S.G. and Tobin, R.C. (2009) Recreational fishers' attitudes towards the 2004 rezoning of the Great Barrier Reef Marine Park. Environmental Conservation 36(3): 245-252.

Walker, G. B. (2007) Public participation as participatory communication in environmental policy decision-making: From concepts to structured conversations. Environmental Communication: A Journal of Nature and Culture 1(1): 99-110.

Weible, C.M. (2008) Caught in a maelstrom: Implementing California marine protected areas. Coastal Management 36(4): 350-373.

Wheeler, M., Chambers, F.M.J., Sims-Castley, R., Cowling, R.M. and Schoeman, D.S. (2008) From beans to breams: how participatory workshops can contribute to marine conservation planning. African Journal of Marine Science 30(3): 475-487. 
Williamson, D.H., Russ, G.R. and Ayling, A.M. (2004) No-take marine reserves increase abundance and biomass of reef fish on inshore fringing reefs of the Great Barrier Reef. Environmental Conservation 31(2): 149-159.

Willis, T.J., Millar, R.B., Babcock, R.C. and Tolimeiri, N. (2003) Burdens of evidence and the benefits of marine reserves: putting Descartes before des horse. Environmental Conservation30(2): 97-103.

Wong, S.W.Y., Leung, P.T.Y., Djurisic, A.B. and Leung, K.M.Y. (2010) Toxicities of nano zinc oxide to five marine organisms: influences of aggregate size and ion solubility. Analytical and Bioanalytical Chemistry 396(2): 609-618.

\section{About the Author}

Daryl McPhee

Associate Professor Daryl McPhee is from Bond University on Queensland's Gold Coast and is the the author of the textbook Fisheries Management in Australia. He has published numerous papers and reports on fisheries management and in particular recreational fisheries management. His knowledge is interdisciplinary and while trained in marine science he has integrated this knowledge with economics and sociology. 